\title{
Optimization of certain physical parameters for the mariculture of Gracilaria edulis (Gmelin) Silva in Minicoy lagoon (Laccadive Archipelago)
}

\author{
P. Kaladharan ${ }^{*}$, K. Vijayakumaran, V. S. K. Chennubhotla \\ Research Centre of Central Marine Fisheries Research Instirute, Minicoy 682559, India
}

Accepted 23 August 1995

\begin{abstract}
Mariculture of the agar-yielding, red seaweed, Gracilaria edulis (Rhodophyta) was conducted in Minicoy lagoon during 1990-1992. Experiments were conducted on dry matter accumulation, effects of planting density, depth of water above culture nets, periodic cleaning for removal of epiphytes, grazing and the yield as well as regeneration of $G$. edulis after successive harvests to understand the optimum requirements of this seaweed. Six culture methods were tested and the yields oblained were compared to arrive at a culture method suitable for Minicoy lagoon.
\end{abstract}

Keywords: Gracilaria edulis; Mariculture; Optimum parameters

\section{Introduction}

Minicoy Atoll $\left(08^{\circ} 18^{\prime} \mathrm{N}\right.$ and $\left.73^{\circ} \mathrm{E}\right)$ of the Laccadive Archipelago in the Arabian sea has a vast lagoon measuring about $9.66 \mathrm{~km}^{2}$ (Gardiner, 1903). The intertidal belt is formed of Thalassia beds accommodating more than 30 genera of seaweeds (Kaliaperumal et al., 1989). However, the commercially-important, agar-yielding Gracilaria edulis (Gmelin) Silva was not found in Minicoy Atoll prior to its introduction by the Central Marine Fisheries Research Institute, Cochin in 1989 (Kaladharan and Chcnnubhotla, 1993).

It is estimated that about $40000 \mathrm{t}$ (fresh wt.) of seaweed are exploited for extraction of agar-agar and alginic acid every year in India. As the exploitation of desired species

\footnotetext{
${ }^{*}$ Corresponding author at: C.M.F.R.I., P.B. No.1603, Cochin 682014, India. 
of seaweeds has exceeded their regeneration capacity in natural beds, it has now become necessary to attempt cultivation on a large scale. Mariculture of Gracilaria is challenging, as the methods of cultivation have yet to be developed successfully (Anonymous, 1989). With a view to determining the feasibility of Gracilaria cultivation in the lagoons of the Laccadive Islands, preliminary studies were carried out after March 1989. In this paper we describe attempts to optimize some of the physical conditions required for obtaining maximum yields consistently. We also compare the yields of Gracilaria cultivated in Minicoy lagoon employing different culture methods.

\section{Material and Methods}

Gracilaria edulis stocks were brought to Minicoy from Kavaratti Island $\left(10^{\circ} 33^{\prime} \mathrm{N}\right.$, $\left.72^{\circ} 36^{\prime} \mathrm{E}\right)$ of the Laccadive Archipelago and from the Gulf of Mannar $\left(09^{\circ} 17^{\prime} \mathrm{N}\right.$, $\left.79^{\circ} 06^{\prime} \mathrm{E}\right)$ of the Tamilnadu coast for cultivation. Gracilaria was cultivated on $2 \mathrm{~m} \times 2 \mathrm{~m}$ nets ( $20 \mathrm{~cm}$ mesh) made of either nylon or coir (obtained from coconut husks), and on $10 \mathrm{~m}$ long ropes. Fronds of Gracilaria were inserted between the twists of rope. Six culture methods were tested:

1. In the floating net raft method, nets or ropes were kept afloat by tying them to four wooden stakes.

2. For bottom-set nets or ropes, stone sinkers were used to anchor the culture nets or ropes to the bottom.

3. Fronds of Gracilaria were tied to small coral stones using either coir ropes or thin nylon thread and these stones were broadcast on the lagoon bottom.

4. In the cage method, a cylindrical wooden cage, $1.5 \mathrm{~m}$ long and $0.5 \mathrm{~m}$ diameter, was covered with $5 \mathrm{~cm}$ mesh net to prevent entry of herbivorous fishes into the cage where culture ropes were tied. These cages were positioned in the water with floats and sinkers so as to keep them floating vertically.

5. Two types of insertion pattern were replicated to study the effect of planting density on the yield. In the compact planting pattern $5 \mathrm{~g}$ fronds were inserted every $10 \mathrm{~cm}$, whereas in the wide planting pattern, $10 \mathrm{~g}$ fronds were inserted every $20 \mathrm{~cm}$.

6. In a further experiment, one set of culture ropes and nets were cleaned at a weekly interval and another set (control) were left uncleaned. While cleaning, epiphytes and other weeds were hand-picked from the culture nets and ropes and the adhering microflora was removed by splashing the ropes or nets in water.

Yield was calculated from the harvested materials the ratio of the fresh weight of harvested material (W1) to that of the initial planting stock material (W0). The specific growth per day $(\mu)$ was calculated as per the logarithmic formula given by Patwari and Vandermeer, 1984. Entire fronds as well as fronds cut into tip, middle and base every 2-3 cm length from the tip, were dried at $90 \pm 1^{\circ} \mathrm{C}$ in a hot air oven until a constant dry weight was obtained. The results obtained were subjected to an ANOVA and $t$-test (Cochran and Cox, 1957; Freund and Walpole, 1987). A multiple range test (Duncan, 1955) was applied to separate means whenever values of $F$ were significant in the ANOVA. 


\section{Results}

The dry matter percentage in the fronds of Gracilaria showed an increasing trend over 45 days, when it reached a maximum of $20 \%$ (Table 1). The results tested by ANOVA indicated that the increase in dry matter up to 45 days was significant $(P<0.05)$. The mean values of dry matter at the base $(13.89 \%)$, middle $(15.69 \%)$ and tip $(14.76 \%)$ of the fronds indicated non-uniformity in accumulation of dry matter along the fronds. The ANOVA results showed the difference to be significant $(P<0.05)$ between the base and middle of the fronds but not between the middle and tip of the fronds.

The average yield of harvested fronds from the compact planting was 2.48 times the quantity of initial planting material, whereas that from the wide planting pattern was only 1.97 times. The difference between the above values was significant $(P<0.05)$, indicating the desirability of a compact planting pattern.

The depth of water above culture nets or ropes had a considerable effect on the yield of Gracilaria cultivated in Minicoy lagoon. The maximum yield obtained was at a depth of 40-50 cm (Table 2) and was significantly $(P<0.05)$ different from the yields at a depth of $0-25 \mathrm{~cm}$ as well as at a depth of more than $100 \mathrm{~cm}$.

The mean yield from the nets or ropes which were subjected to weekly cleaning was 4.133, significantly higher $(P<0.1)$ than that from the uncleaned ropes or nets $(2.142)$. The yield from the cage method of cultivation (4.633) was significantly $(P<0.01)$ higher, almost ten times that from the unprotected ropes $(0.458)$. Grazing was observed to be most severe during the post monsoon months (October-February). Rabbit fishes,

Table 1

Dry matter percentage of Gracilaria cultivated in Minicoy lagoon $(F=2.71$; d.f. $=4,20 ; P<0.05)$. Means followed by different letters are significantly different at $P<0.05$

\begin{tabular}{lll}
\hline Treatment & Period of growth(days) & Mean Dry weight(\%) \\
\hline A & 10 & $12.0 \mathrm{a}$ \\
B & 15 & $14.7 \mathrm{~b}$ \\
C & 30 & $17.2 \mathrm{c}$ \\
D & 45 & $20.4 \mathrm{~d}$ \\
E & 60 & $20.2 \mathrm{~d}$ \\
\hline
\end{tabular}

Table 2

Effect of water depth above the net/rope on the relative yield of Gracilaria $(F=3.49 ;$ d.f. $=3,12 ; P<0.05)$. Means followed by different letters are different at $P<0.05$

\begin{tabular}{llll}
\hline Treatment & $\begin{array}{l}\text { Depth above } \\
\text { net } / \text { rope }(\mathrm{cm})\end{array}$ & $\begin{array}{l}\text { Mean relative } \\
\text { yield }(\mathrm{W} 1 / \mathrm{W} 0)\end{array}$ & $\begin{array}{l}\text { Specific growth } \\
\text { rate (wt\%/day) }\end{array}$ \\
\hline $\mathrm{A}$ & $0-25$ & $2.160 \mathrm{a}$ & $1.295 \mathrm{a}$ \\
$\mathrm{B}$ & $40-50$ & $3.240 \mathrm{~b}$ & $1.953 \mathrm{~b}$ \\
$\mathrm{C}$ & $70-100$ & $2.815 \mathrm{~b}$ & $1.785 \mathrm{~b}$ \\
$\mathrm{D}$ & $>100$ & $1.953 \mathrm{c}$ & $1.130 \mathrm{c}$ \\
\hline
\end{tabular}


Table 3

Yield from successive harvests of Gracilaria cultured in Minicoy lagoon (for ropes as well as nets, $F=4.07$; d.f. $=3,8 ; P<0.05$ calculated value for nets 264.26 and for ropes 227.27 )

\begin{tabular}{lllllrr}
\hline Treatment & Harvest & \multicolumn{2}{l}{ Mean relative yield } & & \multicolumn{2}{l}{ Specific growth rate } \\
\cline { 3 - 4 } & & Rope & Net & & Rope & \multicolumn{2}{c}{ Net } \\
\hline A & I & $3.24 \mathrm{a}$ & $3.80 \mathrm{a}$ & & $1.99 \mathrm{a}$ & $2.26 \mathrm{a}$ \\
B & II & $2.30 \mathrm{~b}$ & $3.10 \mathrm{a}$ & & $1.14 \mathrm{~b}$ & $1.19 \mathrm{a}$ \\
C & III & $0.68 \mathrm{c}$ & $1.94 \mathrm{~b}$ & & $-0.65 \mathrm{c}$ & $1.12 \mathrm{~b}$ \\
D & IV & $0.29 \mathrm{c}$ & $0.73 \mathrm{c}$ & & $-0.53 \mathrm{c}$ & $-2.11 \mathrm{c}$ \\
\hline
\end{tabular}

Siganus sp. and Kaiphosus sp. were considered as main grazers in Minicoy lagoon. Rope cultured fronds suffered greater attacks from the grazers compared to those cultured on nets. The fronds projecting from the twists of the coir substratum were completely removed and the regenerating parts were subsequently eaten by the grazers on a few occasions.

Regrowth of Gracilaria from the remnants of the previous harvests declined rapidly on both rope and nets and the yield and growth rate became very poor by the fourth harvest (Table 3$)$. The mean yields from successive harvests were significantly $(P<0.05)$ lower.

\section{Discussion}

The ratio between fresh to dry weight of $G$. edulis was $5: 1$, which is preferred to the ratio (7:1) reported from Thailand for some other species of Gracilaria (FAO, 1990). As the dry matter in the fronds did not increase further after 45 days of growth (Table 1), a 45-60 day harvest interval is considered optimum to maximize dry matter percentage. The fronds can be clipped from the culture substratum, leaving the base for regrowth, to save the time and labour of replanting however, subsequent harvests are not so good as the initial harvest.

The depth of water above the culture substratum had a considerable effect on the growth and yield of Gracilaria (Table 2). The lower yield obtained at near surface could be attributed to the adverse effects of intense illumination and desiccation of fronds during low tide. At depths beyond $100 \mathrm{~cm}$ on the contrary, lower yield could be due to the lack of sufficient quantum of light. Significant difference in the yield of Gracilaria from the uncleaned ropes or nets could be due to the fact that removal of epiphytes and other seaweeds reduced competition for nutrients and light and such periodical removal of microflora and other attached fauna from the fronds ensured more even exposure to light.

Grazing is one of the most serious problems in seaweed cultivation (Anonymous, 1989). In the present study, grazing was experimentally checked by growing the culture ropes inside a wooden cage covered with nylon net. The decline in the yield and growth rate of Gracilaria during successive harvests (Table 3) agrees well with earlier reports on loss of vigour and retardation of growth in Gracilaria sp. (FAO, 1990) and lower 
Table 4

Summary of culture methods tried in Minicoy lagoon

\begin{tabular}{lll}
\hline Method & $\begin{array}{l}\text { Mean relative } \\
\text { yield }\end{array}$ & $\begin{array}{l}\text { Specific growth } \\
\text { rate }\end{array}$ \\
\hline 1. Lagoon bottom (fronds tied to coral stones) & 3.34 & 2.035 \\
2. Floating rope (fixed on four wooden stakes) & 5.50 & 2.870 \\
3. Rope settled to bottom(on stone sinkers) & 2.01 & 1.750 \\
4. Net rafts fixed on four wooden stakes & 5.88 & 2.990 \\
5. Net settled to bottom on stone sinkers & 3.87 & 3.000 \\
6. Cage method covered by net) & 4.63 & 2.660 \\
\hline
\end{tabular}

growth rates in cultured Gelidiella acerosa than in natural stocks (Rama Rao and Subbaramaiah, 1977). As the yield declined steeply between the second and third harvests, it would be desirable to plant new fronds after the second harvest.

A summary of results from the various culture methods tried in Minicoy lagoon are presented in Table 4. Sub-surface nets and ropes were found to give better yields than those kept at the surface or near the bottom. Nets gave better results than the ropes. The cage method was very effective in controlling grazers, but due to silt deposition and shading posed by excessive foliage on the mesh, frequent cleaning and maintenance was necessary. Hence, it is not economically feasible.

Mariculture of Gracilaria in Minicoy lagoon and in the lagoons of other atolls of Laccadive Archipelago can be taken up as a spare time project by the fishermen in areas where problems of silt, wind and wave action are at a minimum. Coir ropes are fabricated locally from the retted coconut husks and are readily available. Taking all these points into account, the floating raft method (net or rope) can be considered appropriate for mass culture of Gracilaria in lagoons of Minicoy and other atolls of Laccadive Archipelago.

\section{Acknowledgements}

The authors are grateful to Dr. P.S.B.R. James, the Director, CMFRI for encouragement and to $\mathrm{O}$. Ismail and N. Pookoya for their field assistance.

\section{References}

Anonymous, 1989. Report of International Seminar on Gracilaria: Production and Utilisation in the Bay of Bengal, 23-27 October, Songkla, Thailand. Fishing Chimes, 9: 17-53.

Cochran, W.G. and Cox, G.M., 1957. Experimental Designs. Wiley, New York.

Duncan, D.B., 1955. Multiple range and multiple $F$ tests. Biometric, 11: 1-42.

FAO, 1990. Training Manual on Gracilaria culture and seaweed processing in China, 6, 85 pp.

Freund, J.E. and Walpole, R.E., 1987. Mathematical Statistics. Prentice Hall, New Delhi, 608 pp.

Gardiner, J.S., 1903. The fauna and geography of the Maldive and Laccadive Archipelagos. Vol. II, Cambridge University Press.

Kaliaperumal, N., Kaladharan, P. and Kalimuthu, S., 1989. Seaweed and seagrass resources. Bull. Cent. Mar. Fish. Res. Inst., 43: 162-170. 
Kaladharan, P. and Chennubhotla, V.S.K., 1993. Introduction and growth of Gracilaria edulis in Minicoy lagoon. Fishing Chimes, 13: 55.

Patwari, U. and Vandermeer, J.P., 1984. Growth experiments on autopolyploids of Gracilaria tikvahiae. Phycologia, 23: 21-27.

Rama Rao, K. and Subbaramaiah, K., 1977. Regeneration and regrowth of Gelidiella acerosa (Forssk) Feld et Hamel at Kilakkarai, South Eastern shores of India. Indian J. Mar. Sci., 6: 175-177. 